\title{
Marcescin, an Antibiotic Substance from Serratia marcescens
}

\author{
By A. T. FULLER AND JEAN M. HORTON \\ National Institute for Medical Research, Mill Hill, London, N.W. 7
}

\begin{abstract}
SUMMARY: Marcescin, a thermostable polypeptide isolated from a strain of Serratia marcescens inhibits the growth of Corynebacterium diphtheriae at $0.01 \mu \mathrm{g} . / \mathrm{ml}$. and Staphylococcus aureus at $0.1 \mu \mathrm{g} . / \mathrm{ml}$. It is produced in good yield in $18-36 \mathrm{hr}$. at $2^{\circ}$ in an aerated ammonium citrate glycerol medium. It was very toxic to mice and in sublethal doses failed to protect mice against sensitive organisms. It is very strongly adsorbed by bacteria so it is not possible to say whether it is bacteriostatic or bactericidal in high concentration.
\end{abstract}

Serratia marcescens, formerly known as $\boldsymbol{B}$. prodigiosus, is a red-pigmented nonsporing Gram-negative bacterium. There are several records of antibiotic activity in the Serratia group, but practically all observers (e.g. Hettche, 1932) have ascribed it to prodigiosin, the red pigment. Eisler \& Jacobsohn (1985) and Lichstein \& van der Sand (1946), however, found evidence of a colourless, heatstable antibiotic, which they did not isolate.

The substance described below, marcescin, is a colourless thermostable polypeptide having a powerful inhibitory action on the growth of Pasteurella septica, and on Corynebacterium diphtheriae and other Gram-positive bacteria. It was obtained from a bacillus (strain $82 \mathrm{~B}$ ) isolated from soil and identified as Serratia marcescens.

\section{EXPERIMENTAL}

Isolation of the organism. After many trials the following technique was adopted for isolating antagonistic organisms from soil. Suitably diluted soil samples were plated and colonies allowed to develop for 4 days at $23^{\circ}$. The indicator organism (Staphylococcus aureus or Escherichia coli) was added in $1.5 \%$ nutrient agar pipetted on to the surface of the plates, which were incubated overnight at $37^{\circ}$. Strains antagonistic to the indicator organism were isolated and tested against eight to ten species of pathogenic bacteria.

Determination of antibiotic titre. The serial dilution method was employed using $200 \mu$ l. of broth seeded with $10 \mu$ l. of a 1/500 dilution of an overnight broth culture of Staphylococcus aureus. The results were often inconsistent owing to the appearance of resistant organisms with a granular type of growth. Tests were therefore made in duplicate. A unit of marcescin activity was provisionally defined as the amount which in $1 \mathrm{ml}$. was able to prevent the overnight growth of Staph. aureus. The number of units/g. is therefore the limiting dilution at which the material was active. 


\section{Description of the antibiotic producing Serratia strain}

The bacillus (82 B) is motile, Gram-negative, and produces a pink pigment in broth cultures in 2-3 days at $28^{\circ}$. Twenty-four hour colonies on agar are circular with an entire edge, a glassy surface, and a yellowish coloration later becoming pink. It grows moderately well without forming pigment at $37^{\circ}$. The optimum temperature for growth and pigment production is about $23^{\circ}$. On nutrient agar the organism throws white variants which breed true for several subcultures and produce antibiotic as efficiently as the pigmented strains. Gelatin cultures liquefy in 1-2 days and a milk medium is coagulated in 2 days; acetylmethylcarbinol positive, indole negative. In peptone water acid and gas are produced from glucose, sucrose, raffinose, fructose, maltose, galactose, xylose and mannitol, but not from lactose, arabinose or dextrin. Lactose is fermented in absence of peptone, e.g. in aqueous solution or milk. These properties place the organism in the family Enterobacteriaceae, tribe Serrateae, genus Serratia (Bergey, 1948).

The organism differs culturally from $S$. piscatorum; from $S$. plymuthicum in failing to produce gas from lactose; and from $S$. kilensis in its ability to form acetylmethylcarbinol and in absence of pigmentation at $37^{\circ}$. The ultra-violet absorption spectrum of the pigment from strain $82 \mathrm{~B}$ in amyl alcohol showed a closer similarity to that from $S$. marcescens N.C.T.C. 4612 than to that from S. kilensis N.C.T.C. 4619.

The pink pigment of $82 \mathrm{~B}$ is sparingly soluble in water and soluble in ethanol, ether and chloroform. In this property, and in its failure to produce a conspicuous pellicle on gelatin (but see below), its failure to produce indole, its liquefaction of gelatin and its coagulation of milk (but see below) the organism resembles $S$. marcescens (Bergey, 1948). It also has affinities with $S$. indica, but it is doubtful whether $S$. indica is really distinct from $S$. marcescens. $S$. indica is stated by Breed \& Breed (1926) to differ from $S$. marcescens in producing an orange pellicle on gelatin, in growing in a $\mathrm{KCl}$ urea glucose medium, and in producing a gas which is solely $\mathrm{CO}_{2}$ from glucose $(S$. marcescens produces some hydrogen as well).

S. indica (N.C.T.C. 2847), S. marcescens (N.C.T.C. 1377, 2302, 2842, 2847 and 3804), and $82 \mathrm{~B}$, were examined by these and other tests to see whether $82 \mathrm{~B}$ resembled marcescens or indica more closely. In a $15 \%$ gelatin stab made up with meat extract all cultures grew well with liquefaction in 1-2 days at $23^{\circ}$. Pellicles occurred at some stage up to 7 days in all cultures except $82 \mathrm{~B}$ and there was no distinction between marcescens and indica. N.C.T.C. 1377 had an orange pellicle at 2 days which later became pink, but the $S$. indica culture was never pigmented. None of the cultures could be made to grow from an inoculum of washed cells in a medium containing $0.5 \% \mathrm{KCl}, 1 \%$ urea and $1 \%$ glucose.

Pederson \& Breed (1928) used large-scale cultures and gas analysis in showing that $S$. marcescens produced hydrogen as well as $\mathrm{CO}_{2}$, whereas $S$. indica produced only $\mathrm{CO}_{2}$ on an inorganic salt glucose medium. We failed to get gas from any of the cultures on an inorganic medium in Durham tubes. In glucose 
peptone water, $82 \mathrm{~B}$ rapidly produced gas, half of which was absorbed by $\mathrm{NaOH}$. Of the other cultures only 1377 and 2302 gave minute amounts of gas which were not completely absorbed by $\mathrm{NaOH}$. In this $82 \mathrm{~B}$ resembles S. marcescens.

None of these tests enabled us to place $82 \mathrm{~B}$ definitely in the marcescens or indica species. The species marcescens is, however, heterogeneous. Reed (1937) by agglutination tests put N.C.T.C. 1877, 2302 and 2446 into one group, and N.C.T.C 2842 and 3804 into another. Taking the strains investigated by Reed, we found that fermentation of raffinose and lactose, reduction of ammonium molybdate to a blue compound (Marchal \& Girard, 1947) and intensity of pigment formation divides them into the same two groups (Table 1). The strains in both groups are strongly proteolytic. $S$. indica, N.C.T.C. 2847, differs from Reed's first groups in failing to clot milk under the test conditions and in poverty of pigment. It is, however, closer to this section group than to Reed's group 2, which differs from group 1 in raffinose fermentation, molybdate reduction and pigment formation. S. marcescens, N.C.T.C. 4612, is an intermediate strain, fermenting raffinose slowly and being weakly proteolytic.

Table 1. Biochemical reactions of strains of Serratia marcescens

\begin{tabular}{|c|c|c|c|c|c|c|c|}
\hline \multirow[b]{2}{*}{$\begin{array}{c}\text { Culture } \\
\text { no. } \\
\text { N.C.T.C. }\end{array}$} & \multicolumn{6}{|c|}{ and Serratia indica } & \multirow[b]{2}{*}{$\begin{array}{l}\text { Pigment } \ddagger \\
\text { formation }\end{array}$} \\
\hline & $\begin{array}{l}\text { Agglutina- } \\
\text { tion by } \\
\text { antiserum } \\
\text { to } 2446^{*}\end{array}$ & $\begin{array}{c}\text { Raffinose } \\
\text { fermen- } \\
\text { tation }\end{array}$ & $\begin{array}{c}\text { Lactose } \\
\text { fermen- } \\
\text { tation }\end{array}$ & $\begin{array}{l}\text { Molybdate } \\
\text { reduction }\end{array}$ & $\begin{array}{l}\text { Gelatin } \\
\text { lique- } \\
\text { faction }\end{array}$ & $\begin{array}{c}\text { Milkt } \\
\text { clotting }\end{array}$ & \\
\hline 1377 & + & - & - & - & ++ & ++ & $+t$ \\
\hline 2302 & + & - & - & - & + & ++ & ++ \\
\hline 2446 & + & - & . & . & + & . & ++ \\
\hline 2842 & - & + & + & + & + & + & - \\
\hline 8804 & - & + & + & + & + & ++ & \pm \\
\hline 4612 & . & \pm & - & . & \pm & - & - \\
\hline 28478 & . & $=$ & - & - & $\overline{+}$ & - & - \\
\hline $82 B$ & . & + & \pm & - & + & - & \pm \\
\hline
\end{tabular}

Strain 82 B corresponds neither to Reed's strains, nor to $S$. indica. Neglecting 4612, the property which differentiates all the strains of $S$. marcescens from the strain of $S$. indica used is that of the rapid clotting of milk by culture filtrates. Culture filtrates from $82 \mathrm{~B}$ fail to do so, and the organism thus resembles $S$. indica in this respect. All the members of the family when grown in a milk medium clot it.

There seems little justification for division of the two species, sinceS. marcescens is heterogeneous (Reed, 1937), and Bergey (1948) suggested that $S$. indica and $S$. marcescens are variants of the same species. We have classified $82 \mathrm{~B}$ as S. marcescens.

Production of antibiotic

The active substance is stable to boiling and is present in the supernatant fluid of boiled cultures. $S$. marcescens is an aerobic organism and needs a good supply of air for rapid growth and adequate antibiotic production. In 
preliminary experiments, shallow layers $(0.5 \mathrm{~cm}$.$) in medicine bottles were$ used.

\section{Effect of medium}

Hartley broth. Maximum yields of 16-160 u./ml. were obtained in 3-5 days at $23^{\circ}$. The $\mathrm{pH}$ of cultures fell to 6.8 on the first day and rose on the second and third days to 8.0 or $8 \cdot 5$, but the change gave no indication of the point of maximum yield. The turbidity of the culture, however, tended to decrease at maximum titre. Antibiotic was not produced at temperatures above $2^{\circ}$, although growth was good. The antibiotic disappeared from sterilized broth cultures in a few days even at $0^{\circ}$.

Chemically defined media. The first basal medium consisted of: $\left(\mathrm{NH}_{4}\right)_{2} \mathrm{SO}_{4}$, 20 g.; $\mathrm{KH}_{2} \mathrm{PO}_{4}, 2 \mathrm{~g}$.; $\mathrm{MgSO}_{4} .7 \mathrm{H}_{2} \mathrm{O}, 0.5 \mathrm{~g}$.; $\mathrm{NaCl}, 0.05$ g.; to 1 l. with water; with an added carbon source. Maximum yields of about 64 u. $/ \mathrm{ml}$. were obtained with $1 \%$ glucose, $2 \%$ mannitol or $0.5 \%$ glycerol, but $1 \%$ sodium citrate gave very low yields.

Supplements of $1 \%$ Amigen (a casein digest from Mead Johnson and Co., Evansville, U.S.A.) or beef juice, with $0.5 \%$ glucose yielded 64-256 u. $/ \mathrm{ml}$. but little with mannitol or glycerol. A supplement of $1 \%$ Bactopeptone with mannitol or glucose suppressed antibiotic formation altogether. Addition of $1 \%$ of corn-steep liquor had no effect.

A medium in which the ammonium sulphate was replaced by ammonium citrate and containing $0.5 \%$ of glycerol gave the most satisfactory results. In ammonium sulphate media, the $\mathrm{pH}$ fell to $4-4.5$ in 2 days, while that with ammonium citrate kept at $\mathrm{pH}$ 6-6.2. The acidity was not the cause of the lower yield since repeated neutralization of the sulphate culture gave no better results, and when the medium was buffered at $\mathrm{pH} 7 \cdot 6$, no antibiotic was produced.

Trace elements had no effect or a deleterious one. $\mathrm{FeSO}_{4} \cdot 7 \mathrm{H}_{2} \mathrm{O}, 10 \mathrm{mg}$. $/$., greatly diminished the yield of antibiotic, except in the presence of casein digests or citrates, when it was without effect. Neither $\mathrm{MnSO}_{4}, \mathrm{ZnSO}_{4}$, or $\mathrm{CaCl}_{2}$ (10 mg./l.) affected the yield. When, however, the medium was prepared with tap-water instead of distilled water, the yield of antibiotic was very low.

\section{Conditions of cultivation}

Shallow layer cultures (1-3 mm.) reached maximum titre more quickly (1 day) than those in deeper layers (10-20 mm.; 3-4 days) and usually yielded more. Increase of the concentration of oxygen in the atmosphere to $50 \%$ did not improve the yield. When inocula varying between $0 \cdot 1$ and $10 \%(\mathrm{v} / \mathrm{v})$ of a vigorously growing culture were used, the largest inoculum gave much the best results, up to $1000 \mathrm{u}$. $/ \mathrm{ml}$. at $42 \mathrm{hr}$. Rapid growth seemed necessary for high yields. Since shallow layers are unsuitable for larger scale preparation, volumes of $2 \mathrm{l}$. in $5 \mathrm{l}$. flasks, aerated through sintered glass disks were used. Six-hourly determinations of titre showed that with a $10 \%$ inoculum maximum yields of up to $2000 \mathrm{u}$./ml. occurred at $18-24 \mathrm{hr}$. at $22-24^{\circ}$ (e.g. Table 2). With this short incubation period foaming was not troublesome. 
Table.2. Production of marcescin in a $3 \%$ ammonium citrate, $0.5 \%$ glycerol medium at $24^{\circ}$

\begin{tabular}{|c|c|c|c|c|c|c|}
\hline & \multicolumn{6}{|c|}{ Time (hr.) } \\
\hline & 6 & 12 & 18 & 24 & $\mathbf{3 0}$ & 36 \\
\hline pH: & $6 \cdot 2$ & $6 \cdot 0$ & $6 \cdot 2$ & $6 \cdot 2$ & $6 \cdot 1$ & $6 \cdot 2$ \\
\hline Opacity*: & 0.07 & $0 \cdot 1$ & $0 \cdot 14$ & $0 \cdot 21$ & $0 \cdot 23$ & $0 \cdot 14$ \\
\hline Pigment : & + & ++ & + & \pm & - & - \\
\hline Units/ml.: & 16 & 1000 & 1000 & $\overline{\mathbf{1 6 0}}$ & 240 & 150 \\
\hline
\end{tabular}

In citrate glycerol media, neither $\mathrm{pH}$ nor opacity measurements helped to determine the point of maximum yield; nor did estimation of the residual glycerol in the medium, since maximum titres occurred when only a small part of the glycerol had disappeared. Attempts to assess the activity rapidly by testing the inhibition of reduction of methylene blue by Staphylococcus aureus were not satisfactory. Citrate cultures had the advantage over broth that after sterilization they lost little activity in 2 weeks at room temperature.

The preferred method for the production of the antibiotic was as follows. The medium consisted of: ammonium citrate, 30 g.; glycerol, 5 g.; $\mathbf{K H}_{2} \mathbf{P O}_{4}$, 2 g.; $\mathrm{MgSO}_{4} .7 \mathrm{H}_{2} \mathrm{O}, 0.5 \mathrm{~g}$; distilled water $\mathrm{I}$ l.; and was sterilized by autoclaving at $10 \mathrm{lb}$. for $15 \mathrm{~min}$.

The temperature of incubation was 22-24. ${ }^{\circ}$. Cells from a 1 day slope were seeded into $40 \mathrm{ml}$. of medium which was incubated for $28 \mathrm{hr}$. in a shallow layer, and transferred to a flask containing $200 \mathrm{ml}$. of medium in a layer $10 \mathrm{~mm}$. deep. Twenty-four hours later, the contents were added to 21 . of medium in a 51 . flask, which was aerated vigorously for $18 \mathrm{hr}$. The culture was sterilized by boiling, assayed, and kept until the next day, when it was processed if the titre was satisfactory.

During the course of the work, the titres of the ammonium citrate glycerol cultures fell from batch to batch, from the original $1000 \mathrm{u}$. $/ \mathrm{ml}$. to $20 \mathrm{u}$. $/ \mathrm{ml}$., and we were unable to regain the conditions necessary for high yields. We could find no reason for this decrease. Different batches of chemicals were tried. The age and temperature of incubation of the primary and secondary cultures were varied, and the stock culture, which had been passaged for 12 months, was replaced by a culture dried at the beginning of the work, but no difference was observed. Pigmented and achromogenic variants of the strain gave similar results.

There were indications that the strain had become more sensitive to the antibiotic. Originally it would grow in $1000 \mathrm{u} . / \mathrm{ml}$., but later it could withstand only 40-160 u./ml. A culture of Serratia marcescens was trained to grow in the presence of $1000 \mathrm{u} . / \mathrm{ml}$., with the intention of using it to prepare the antibiotic; but it lost its resistance at the first subculture in marcescin-free medium and so had no advantage over the stock culture.

Since the decrease in yield and in the resistance of the culture occurred together and were of the same order, an alternative explanation of the 
phenomenon is that the conditions of testing had been inadvertently changed to make the antibiotic apparently less effective. No evidence for this could be found. The values recorded for the activity of the final product were obtained when low yields were being obtained, and hence under the possibly more stringent conditions of testing.

\section{Antibiotic production by related organisms}

S. kilensis N.C.T.C. 4619 , and S. indica N.C.T.C. 2847 , gave low titres in broth cultures. $S$. marcescens N.C.T.C. 4618, 2446 and 1877 , yielded no antibiotic. Six strains of chromobacteria: Chromobacterium amethystum N.C.T.C. 4737, Chromobact. violaceum 2537, Chromobact. orangium 7185, Chromobact. chocolatum, Chromobact. hiburnicum 3078, and Chromobact. viscosum 2416, gave none or only traces. Four strains of $S$. marcescens, N.C.T.C. 3804, 2302, 4612 and 1877, and $S$. indica 2847, in a synthetic citrate medium, yielded only about $5 \%$ of the antibiotic titre of our strain. The conditions for antibiotic production by these strains were not examined exhaustively nor was the antibiotic produced identified with marcescin. Ourstrain of $S$. marcescens was more actively antibiotic than all other members of the species tested.

\section{Extraction of the antibiotic}

Broth cultures. The antibiotic could be extracted from broth cultures by adsorbing on blood charcoal, eluting with glacial acetic acid and precipitating with 4 volumes of ether. It was further purified by dissolving in water and precipitating by adjustment of the $\mathrm{pH}$ to $7 \cdot 5$.

Citrate cultures. The broth-extraction method failed with citrate cultures. The active substance was adsorbed by charcoal but it could not be removed from any of several grades of charcoal; even when the chareoal was pre-treated with a variety of reagents or after-treated with potassium cyanide solution.

Many other adsorbents were tried, including the oxides, hydroxides, carbonates, phosphates and silicates of $\mathrm{Zn}, \mathrm{Fe}, \mathrm{Al} ; \mathrm{Ca}$ and $\mathrm{Mg}$; fullers' earth, Lloyd's reagent, kaolin, naphthols; benzoic acid, starch, coagulated protein and a variety of zeolites. Many of these adsorbed the active substance, but could not be made to yield it again in satisfactory amounts.

A wide variety of solvents and combinations of solvents, anhydrous or mixed with water, acids or bases was tried, but all failed to give satisfactory recovery. The solvents were formic, acetic and propionic acids, formamide and acetamide, dioxane, phenol, ethyleneglycol, propyleneglycol, glycerol, chlorhydrin, collidine, pyridine, piperidine, diethylamine, tripropylamine, acetone, methanol, ethanol, isopropanol and $n$-butanol.

Some success was achieved by adsorbing on acid-treated Decalso F, a cation exchanger (Permutit Ltd., London), and eluting with $0.1 \mathrm{~N}-\mathrm{HCl}$ in water or $75 \%$ ethanol, but the results were variable, and the method was abandoned. The citrate ion seemed to be the cause of the difficulty, and the following method was finally devised for removing it.

Boiled cultures of satisfactory titre were concentrated to one-tenth volume in vacuo, with a drop of tributyl citrate to prevent foaming. After acidifying to 
below pH 1 (green to methyl violet) with 0.4 vol. of concentrated $\mathrm{HCl}$, to convert all the citrate to free citric acid, $\mathbf{3}$ vol. of acetone were added to precipitate bacteria, inert protein and $\mathrm{NH}_{4} \mathrm{Cl}$. After allowing the precipitate to settle for $30 \mathrm{~min}$., the clear supernatant was filtered, and the sludge filtered dry. An equal volume of acetone was added to the combined filtrates, the precipitate allowed to settle, the clear liquid siphoned off and the precipitate filtered dry. The filtrate contained the citric acid. The precipitate, which contained the antibiotic with much $\mathrm{NH}_{4} \mathrm{Cl}$, was dissolved in water equal in volume to the original concentrate and acidified to $\mathrm{pH}$. The flocculent precipitate of low activity was removed and extracted with a little water. The combined extracts were adjusted to $\mathrm{pH} 9$ with aq. ammonia (sp.gr.0.880) to precipitate the antibiotic, and allowed to settle overnight. The precipitate was collected by siphoning and centrifuging, dissolved in water and adjusted to $\mathrm{pH}$ 3. A small inactive precipitate was removed and the liquid again adjusted to $\mathrm{pH} 9$. The precipitate was collected by siphoning, centrifugation and finally filtration through a no. 3 sintered glass filter. The precipitate was thixotropic and the centrifuged deposit held large amounts of water, which could be removed only slowly. The precipitate was stirred with several volumes of acetone and filtered, and the process repeated with acetone and then ether and finally dried in the vacuum desiccator.

The yield of antibiotic was $65-100 \%$ of that demonstrable in the culture fluid. This figure is surprisingly high, and may be due in part to removal of antibiotic adsorbed on the bacteria.

A portion of the crude antibiotic preparation was soluble in $75 \%$ aq. acetone; this was of low activity. By repeated extraction with neutral $75 \%$ aq. acetone $1.11 \mathrm{~g}$. of material of activity 700,000 u.g. was removed from $3.85 \mathrm{~g}$., leaving a main fraction of 7 million $u$./g. This fraction gave a violet biuret reaction, a positive arginine test and a strong ninhydrin reaction after hydrolysis with acid. It contained $0.8 \%$ phosphorus, and $0.3 \%$ sulphur: The Moliseh test was positive and corresponded to about $1.2 \%$ carbohydrate. It was necessary to eliminate the haemorrhagic polysaccharide obtained from $S$. marcescens by Hartwell, Shear \& Adams (1948) as a possible cause of activity.

\section{Further purification}

Fractionation from organic solvents. Marcescin is soluble in aqueous organic solvents (e.g. $65 \%$ acetone) and portions are precipitated when the anhydrous solvent is added. No useful separation resulted from such treatment with a variety of solvents. Extraction with organic solvents in which the antibiotic was only partly soluble was also of little use, although the soluble fractions tended to be lower in activity. Table 3 gives typical results. Fractional precipitation by acetone from solutions in organic solvents was handicapped by. the tendency of the substance to precipitate as a voluminous jelly. Marcescin $(5 \mathrm{u} . / \mu \mathrm{g}$.) was fractionally precipitated by. acetone from solution in various buffers. The precipitated portion was lower in activity the nearer the reaction was to neutrality, but no great purification resulted (Table 4).

Fractionation by isoelectric precipitation. Marcescin is soluble in dilute acid but the solution becomes more opalescent as it is neutralized. A $2 \mathrm{mg} . / \mathrm{ml}$. 
Table 3. Fractionation of marcescin from aqueous organic solvents

\begin{tabular}{|c|c|c|c|c|c|}
\hline \multirow[b]{3}{*}{ Solvent } & \multirow[b]{3}{*}{ Mg. treated } & \multicolumn{4}{|c|}{ Fraction } \\
\hline & & \multicolumn{2}{|c|}{ Soluble } & \multicolumn{2}{|c|}{ Insoluble } \\
\hline & & Mg. & $\begin{array}{l}\text { Activity } \\
\text { (u. } / \mu \mathrm{g} .)\end{array}$ & Mg. & $\begin{array}{l}\text { Activity } \\
\text { (u. } / \mu \mathrm{g} .)\end{array}$ \\
\hline $66 \%$ dioxane & $14 \cdot 2$ & $\mathbf{8 \cdot 9}$ & $2 \cdot 7$ & $\mathbf{5} \cdot \mathbf{3}$ & 4 \\
\hline $50 \%$ pyridine & 7 & $1 \cdot 7$ & $\mathbf{3} \cdot \mathbf{2}$ & $4 \cdot 9$ & $\mathbf{3 \cdot 2}$ \\
\hline $90 \%$ piperidine & 16 & $\mathbf{3}$ & 0.5 & - & . \\
\hline $72 \%$ piperidine & $*$ & $3 \cdot 4$ & $\mathbf{3}$ & •. & - \\
\hline $45 \%$ piperidine & $*$ & $4 \cdot 8$ & 6 & $7 \cdot 4$ & $\mathbf{3}$ \\
\hline
\end{tabular}

Table 4. Fractional precipitation of marcescin with acetone from buffer solutions

Starting material contained $5 \mathbf{u} . / \mu \mathrm{g}$.

$\begin{array}{cccc}\begin{array}{c}\text { Vol. } \\ \text { acetone } \\ \text { added }\end{array} & \text { Precipitated portion as percentage of original } \\ 4 & \text { Activity u./ } \mu \mathrm{g} . & \text { Weight } & \text { Activity } \\ 5 & 1 & 25 & 5 \\ 4 & 2 & 10 & 4 \\ 5 & 3 \cdot 6 & 3 & 2 \\ 4 & 4 & 30 & 24\end{array}$

solution adjusted to $\mathrm{pH} 6.8$ and left overnight gradually developed a precipitate weighing $c .30 \%$ of the original. The activity, toxicity and absorption spectrum of this fraction were no different from those of the original material.

On the alkaline side of $\mathrm{pH} 9$ only traces of material remained soluble, so fractionation was not possible in that $\mathrm{pH}$ range. When excess of $\mathrm{NaOH}$ is added to an acid solution, the marcescin remains in solution for some time but precipitates after a few hours.

The isoelectric precipitate is soluble in $65 \%$ acetone, but is less soluble on the acid and alkaline sides of this point. Precipitates obtained by small adjustment of the $\mathrm{pH}$ of acetone solutions of the isoelectric precipitate proved to be very little different in activity from the main fraction.

\section{Chromatographic separation}

Paper chromatograms. A $1 \mathrm{mg} . / \mathrm{ml}$. solution of marcescin was applied as a narrow band near to one end of a sheet of Whatman No. 1 filter-paper; after drying it was cut up into strips which were treated with solvents by capillary ascent in a closed water-saturated atmosphere. The bands were made visible by holding the strips in ammonia vapour for a short time, painting with a $0.1 \%$ solution of bromophenol blue and washing out the excess of reagent by immersing in two or three changes of water.

When dilute acids travel along filter-paper the acid usually does not extend as far as the water. These fronts are called the 'acid front' and the 'solvent front' respectively. Hydrochloric acid as weak as $0.05 \mathrm{~N}$ moved the antibiotic 
completely to form a sharp band at the acid front. Phosphoric acid did likewise down to $0.2 \%$, but at $0.08 \%$ the band was wide and trailing with no visible separation; $0.06 \mathrm{M}-\mathrm{KH}_{2} \mathrm{PO}_{4}$ was not sufficiently acid to move the antibiotic from its starting-point, but mixtures with from 3 to $0 \cdot 1$ volumes of $1 \%$ phosphoric acid gave a separation, one band going to the acid front and the other remaining in the original position. Mixtures of dilute phosphoric acid or of 1-2 \% acetic acid with 5-10\% of ammonium sulphate gave better band separation. In general, aqueous solutions having a $\mathrm{pH}$ of about 3 and containing some salt were able to effect separation. The salt probably causes dissociation of a complex.

It is evident that in order to separate protein mixtures the acidity must be as low as possible to get the biggest advantage from the different degrees of ionization of the components, while still being high enough to produce some movement of the material. The results with saturated aqueous $(83 \%) n$-butanol were disappointing. Mixed with hydrochloric acid up to $5 \mathrm{~N}$ or with toluenesulphonic acid up to $4 \%$, the material moved as a whole. When the hydrochloric acid concentration was kept constant and the butanol varied between 50 and $70 \%$, the band grew more diffuse and travelled less as the butanol concentration increased. With the butanol at $75 \%$ and the $\mathrm{HCl}$ varying from 0.25 to $1 \mathrm{~N}$, the band became more diffuse as the acid became weaker, but no separation of bands was observed. In mixtures with caustic soda or aqueous organic bases no band movement occurred. Two per cent benzoic acid or $2 \%$ citric acid in $83 \% n$-butanol were not sufficiently acid to move the band, but with $1 \%$ acetic acid there was some movement, and with $0.1 \%$ phosphoric acid or $1 \%$ trichloroacetic acid there was some separation into two components.

No separation resulted from the use of acetone (10-80\%) methanol, ethanol, isopropanol or dioxane in combination with dilute acids.

Silica gel columns. In view of the indications of heterogeneity, silica gel columns were used in an attempt to isolate definite fractions. Acid-washed silica gel of 40-60 mesh was adjusted to $\mathrm{pH} 6$ with a phosphate buffer. A $19 \times 0.7 \mathrm{~cm}$. column containing $7 \mathrm{~g}$. silica gel adsorbed about $100 \mathrm{mg}$. of marcescin at $\mathrm{pH} 6$. It was then washed successively with $0.2 \mathrm{M}$ phosphate buffers of $\mathrm{pH} 5,4$ and 3 , acids of increasing strength, first aqueous and then in $60 \%$ acetone. Fractions were examined by adding ammonia to samples of effluent at frequent intervals and noting any precipitation, the eluent being changed when only a faint turbidity was produced.

Precipitable material started to come through at pH 5.8. Several fractions were collected which did not differ greatly in activity. They were combined to give four main ones, as shown in Table 5. In contrast to the starting material, however, they proved capable of a partial separation by isoelectric precipitation into a pigmented acidic fraction of low activity (under 1 million u./g.) and a highly active colourless basic fraction ( 8 million $u . / g$.$) . The more acid the$ point of precipitation, the lower was the activity (Table 5).

A second similar column was eluted exhaustively with a pH 5 buffer, and then 0.5 N-HCl and a 60:40 mixture of acetone and $\mathrm{N}-\mathrm{HCl}$. In the third and 
fourth colums the buffer was omitted. In these, nearly all the material was recovered by the aqueous eluents (Table 6 ).

Table 5. Isoelectric precipitation of fractions from silica gel

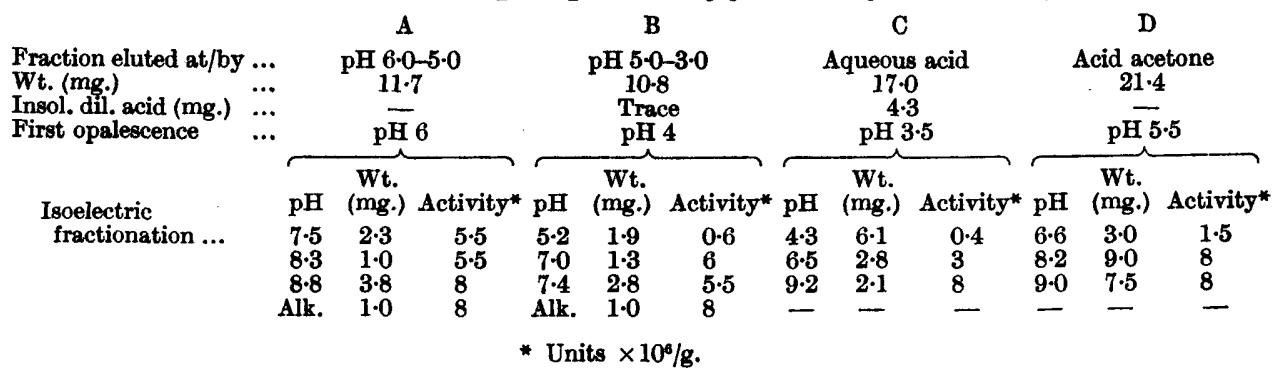

Table 6. Fractionation of marcescin on a silica gel column

\begin{tabular}{|c|c|c|c|c|c|c|}
\hline \multirow[b]{2}{*}{$\begin{array}{c}\text { Starting } \\
\text { material } \\
\text { (mg.) }\end{array}$} & \multicolumn{2}{|c|}{ Soluble in pH 5 buffer } & \multicolumn{2}{|c|}{ Soluble $0.5 \mathrm{~N}-\mathrm{HCl}$} & \multicolumn{2}{|c|}{ Soluble $60 \%$ acid acetone } \\
\hline & $\begin{array}{l}\text { Pptd. } \\
\text { pH } 8 \cdot 2 \\
\text { (mg.) }\end{array}$ & $\begin{array}{l}\text { Pptd. } \\
\text { pH } 9 \\
\text { (mg.) }\end{array}$ & $\begin{array}{l}\text { Pptd. } \\
\text { pH 6.2 } \\
\text { (mg.) }\end{array}$ & $\begin{array}{l}\text { Pptd. } \\
\text { pH g } \\
\text { (mg.) }\end{array}$ & $\begin{array}{l}\text { Pptd. } \\
\text { pH 6.2 } \\
\text { (mg.) }\end{array}$ & $\begin{array}{l}\text { Pptd. } \\
\text { pH } 9 \\
\text { (mg.) }\end{array}$ \\
\hline 108 & $10 \cdot 8$ & 61 & $6 \cdot 7$ & $\mathbf{5} \cdot \mathbf{1}$ & $7 \cdot 7$ & $8 \cdot 2$ \\
\hline 102 & - & - & $16 \cdot 7$ & $60\}$ & & 0.7 \\
\hline 121 & - & - & $16 \cdot 7$ & $71 \cdot 3\}$ & $5 \cdot 1$ & 0.7 \\
\hline
\end{tabular}

The acidic fractions were removed by precipitation at $\mathrm{pH} 6 \cdot 2$, re-dissolved in acid and reprecipitated. They had an activity of less than 1 million $u$./g. The main fractions were precipitated at $\mathrm{pH} 9$ and were active at a dilution of $1 / 8$ million. The fraction taken off by acid acetone contained relatively more of the acid fraction than those by aqueous buffer or acid. Passage through the column affected the equilibrium of the mixture, probably by holding back some of the acid fraction and making the resulting mixture separable.

The activity of the acidic fractions was due to mixture with the basic substance, since the ratio of activities and toxicities was the same for the two fractions, and a small amount of the basic fraction could be recovered by reworking the acidic one. These two fractions corresponded to those separable on paper with $1 \%$ acetic acid containing $7 \%$ ammonium sulphate. The acidic fraction on such a chromatogram did not move in $18 \mathrm{hr}$., whereas the basic fraction in $2 \mathrm{hr}$. moved $4 \cdot 5-5$ in. leaving behind a very small fraction at the starting-point.

It was possible to get an imperfect separation by dissolving the original material in $1 \%$ acetic acid and adding $7 \%$ ammonium sulphate, which precipitated a pigmented fraction. Even after reprecipitation it had an activity of 2.5 million $\mathrm{u} . / \mathrm{g}$. This illustrates that solvents which effect separation on a paper chromatogram give some separation when used in the ordinary way, particularly if one component does not move, since a substance will not move with a solvent unless it is soluble in it. By the carbazole and Molisch tests the pH 9 fraction contained no carbohydrate; it contained $0.03 \%$ of $\mathrm{P}$. 


\section{Marcescin, an antibiotic substance from Serratia marcescens}

The pH 6.2 precipitate contained about $7 \%$ of carbohydrate and $0.9 \%$ of phosphorus, and was probably largely nucleoprotein. A preparation free from carbohydrate was also obtained without the use of silica gel by repeated precipitation at $\mathrm{pH} \mathrm{9,} \mathrm{and} \mathrm{by} \mathrm{repeated} \mathrm{precipitation} \mathrm{of} \mathrm{the} \mathrm{picrate} \mathrm{followed} \mathrm{by}$ solution in $70 \%$ acid acetone and precipitation with excess acetone.

\section{Properties of marcescin}

Marcescin is readily soluble in water at pH 3, but on gradual neutralization the solution becomes increasingly opalescent, and gives a flocculent precipitate at c. pH 7. Precipitation is maximal by $\mathrm{pH} 9$ and is not diminished by more alkali. The solubility at $\mathrm{pH} 7$ is about $0.5 \mathrm{mg} . / \mathrm{ml}$. and at $\mathrm{pH} 9$ $0.02 \mathrm{mg} . / \mathrm{ml}$.

Marcescin dialyses readily through a cellophan membrane from acid solution and less readily from a solution in ammonium citrate or from broth. No active substance passed through a collodion membrane into distilled water from a citrate culture centrifugate.

Marcescin contains $18.3 \%$ of $\mathbf{N}$. It is precipitated by picric acid, the picrate being soluble in $\mathbf{7 0} \%$ acetone and convertible to an active hydrochloride. It is precipitated by trichloroacetic, toluenesulphonic and tannic acids, and by acid dyes, the compound with bromophenol blue being very sparingly soluble. Marcescin gives precipitates with nucleic acid, insulin and heparin. All this is in accord with its being a basic peptide.

The biological activity was not destroyed by incubation with commercial pepsin, commercial trypsin, or a mixture of peptidases extracted from pig intestine. In this it resembles the antibiotic polypeptide, bacitracin (Anker, Johnson, Goldberg \& Melleney, 1948).

Marcescin has strong surface-tension lowering properties; solutions foam if shaken, and it is adsorbed on glass surfaces and many precipitates. Considerable loss occurred in filtering citrate or broth culture fluids through a gradocol membrane (Elford, 1931) of pore size $0.63 \mu$., but all the activity came through one of pore size $0 \cdot 8 \mu$. An $\mathrm{L} 2$ Berkefeld candle at $\mathrm{pH} \gamma$ and Seitz filtration at pH 3 or 6 removed all activity. A small amount passed through a Seitz filter at pH 1.4 or 12.

Marcescin is insoluble in anhydrous ethanol, isopropanol, $n$-butanol, acetone, dioxane, pyridine, morpholine, diethylamine and glacial acetic acid, but it is soluble when the solvents are diluted with water, for example $90 \%$ acetic acid, $90 \%$ phenol, $50 \%$ pyridine, $70 \%$ isopropanol and $65 \%$ acetone. It is precipitated from the last by addition of ammonia. Its adsorption spectrum, similar to that of a histone, showed a small hump at $260 \mathrm{~m} \mu$. (possibly due to arginine) and intense adsorption at $240 \mathrm{~m} \mu$. due to amino-acids.

Marcescin is stable to boiling for at least 3.5 hr. at any pH between 2 and 12. The activity of a $1 \mathrm{mg} . / \mathrm{ml}$. aqueous solution at $\mathrm{pH} 2$, or of a $1 \mathrm{mg} . / \mathrm{ml}$. suspension at $\mathrm{pH} 7$ was unchanged after 8 weeks at room temperature. A solution of $0.01 \mathrm{mg} . / \mathrm{ml}$. at $\mathrm{pH} \mathrm{7,} \mathrm{however,} \mathrm{lost} 80 \%$ of its activity in that time. There was no loss from a $0.01 \mathrm{mg} . / \mathrm{ml}$. solution in $3 \%$ ammonium citrate in 8 weeks. This and other evidence suggests that marcescin may form a complex with the 
citrate ion. Sterile citrate culture fluids were stable for several days at $\mathrm{pH} 3$ or 6 , but not at $\mathrm{pH} \mathrm{9}$. Thus it is more stable in acid than in slightly alkaline solution.

\section{ANTIBACTERIAL PROPERTIES OF MARCESCIN}

Marcescin has a powerful action on Corynebacterium diphtheriae (the growth of which it inhibits at a dilution of 1/100 millions), Pasteurella septica, Clostridium welchii and Staphylococcus aureus. It inhibited the stock testing strain of Staph. aureus at 1/5 million dilution, and two others were more sensitive (up to 1/12 million). It is less active against Mycobacterium tuberculosis and Streptococcus spp. and still less active against Shigella spp. and Escherichia coli. The titres listed in Table 7 were determined in digest broth except for Mycobacterium tuberculosis which was tested in Dubos's medium (Dubos \& Davis, 1946).

Table 7. Activity of marcescin against various pathogenic bacteria

$\begin{array}{lc} & \begin{array}{c}\text { Inhibitory } \\ \text { concentration } \\ (\mu \mathrm{g} . / \mathrm{ml} .)\end{array} \\ \text { Corynebacterium diphtheriae } & <0 \cdot 01 \\ \text { Pasteurella septica } & 0 \cdot 02 \\ \text { Clostridium welchii } & 0 \cdot 03 \\ \text { Staphylococcus aureus (3 strains) } & \mathbf{0 \cdot 0 8 - 0 \cdot 2} \\ \text { Mycobacterium tuberculosis } & \mathbf{0 \cdot \gamma} \\ \text { Haemolytic streptococcus } & \mathbf{0 \cdot 8 - 2 \cdot 0} \\ \text { Streptococcus faecalis } & \mathbf{0 \cdot 8 - 2 \cdot 0} \\ \text { Shigella flexneri } & \mathbf{2 \cdot 0} \\ \text { Escherichia coli } & \mathbf{3 \cdot 2}\end{array}$

\section{Effect of conditions of test on activity}

Although it was difficult to obtain reproducible titres owing to the appearance in the test cultures of resistant organisms, it was not possible to vary activity much by purposeful alterations in the conditions of the titration. There was, for example, little difference in the activity when tested in broth at $\mathrm{pH}$ values from 6 to 8 .

The activity against Escherichia coli was not affected by the presence of complex nitrogen compounds, because the same titre was obtained in digest broth, and in a chemically defined medium of salts, glucose and asparagine. The activity against Staphylococcus aureus in broth was not affected by $1 \%$ glucose or $5 \%$ of a casein digest. In $5 \%$ horse serum broth, however, staphylococci were five times as sensitive to marcescin as in nutrient broth. The antibiotic was unaffected by thiolacetic acid or cysteine.

Concentrations of marcescin less than that necessary to inhibit growth completely, lengthened the lag, i.e. the time before growth was apparent to the naked eye. Thus, $0.01 \mathrm{u}$./ml. inhibited growth for $7 \mathrm{hr}$., and $0.1 \mathrm{u} . / \mathrm{ml}$. for $12 \mathrm{hr}$. Young $(5 \mathrm{hr}$.) cultures seemed equally susceptible to marcescin as older $(22 \mathrm{hr}$.) cultures.

The size of inoculum affected the sensitivity of staphylococci. An inoculum of a 1/2000 dilution of an overnight culture needed four times, and one of 


\section{Marcescin, an antibiotic substance from Serratia marcescens}

$1 / 20,000$ needed twice, the concentration of marcescin which inhibited the growth of an inoculum of a 1/200,000 dilution.

With staphylococci on a cylinder plate, the area of growth inhibition was surrounded by a narrow zone having more intense reducing properties, as shown by methylene blue, than the rest of the culture. This is similar to the zone described by Dufrenoy \& Pratt (1947) on penicillin plates.

Marcescin had little effect on the morphology of bacteria, except to diminish the size of the cells somewhat and in Gram-positive forms to produce a sticky or granular growth that stained Gram-negative.

\section{Adsorption by bacteria}

Staphylococci. Marcescin is strongly adsorbed by bacteria. A washed culture of Staph. aureus of opacity 4 (Brown's opacity tubes, Burroughs Wellcome Co.) was shaken for $2 \mathrm{hr}$. at $37^{\circ}$ with varying concentrations of marcescin in $\mathrm{pH} 7$ phosphate buffer. The bacteria were spun down and the supernatant assayed (Table 8). A loopful of the spun organisms was seeded into $5 \mathrm{ml}$. of fresh broth. Only those which had been treated with the lowest concentration $(20 \mathrm{u} . / \mathrm{ml}$.) grew out in $24 \mathrm{hr}$. The clear broth of the seeded cultures was not inhibitorymuch of the antibiotic was still adhering to the organism and preventing growth. Thus it is impossible to say whether a large concentration of the antibiotic is bacteriostatic or bactericidal, since the cells seeded into the testing broth carry firmly held antibiotic with them. In broth, the adsorption by broth-grown cultures is slightly less complete. A culture of staphylococci shaken with $400 \mathrm{u}$./ml. left $30 \mathrm{u} . / \mathrm{ml}$. in the supernatant. Staphylococci grown in broth adsorbed rather less readily than those grown in a chemically defined medium.

Table 8. Adsorption of marcescin from phosphate buffer

(pH 7) by staphylococci

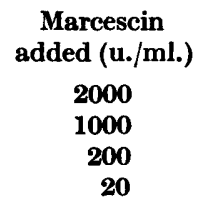

$\begin{array}{cc}\text { Marcescin in } & \text { Growth (24 hr.) on } \\ \text { supernatant (u./ml.) } & \text { explanting organisms } \\ 1600 & - \\ 600 & - \\ 4 & - \\ <2 & +\end{array}$

Other bacteria. Different species of bacteria adsorbed marcescin to about the same extent. Washed organisms suspended in $\mathrm{pH} 7$ buffer containing $100 \mathrm{u}$./ml. and equal in opacity to an overnight culture diminished the concentration in the supernatants to below $2 \mathrm{u}$. $/ \mathrm{ml}$. whether they were staphylococci (sensitive, Gram-positive), Pasteurella septica (sensitive, Gram-negative) or Escherichia coli (fairly resistant, Gram-negative). In another experiment both staphylococci and Esch. coli at about 10 times the concentration of an overnight culture diminished $400 \mathrm{u} . / \mathrm{ml}$. to less than $2 \mathrm{u} . / \mathrm{ml}$., and 2000 to $160 \mathrm{u} . / \mathrm{ml}$., in the supernatant after adsorption. Thus the different sensitivities of bacteria to marcescin did not appear to be due to differences in the degree of adsorption of the substance, nor was it likely that the basic marcescin was being specifically adsorbed on the ribonucleic acid of Gram-positive bacteria. 
To decide whether marcescin did in fact kill bacteria, a substance was sought which would combine with it and neutralize its activity. Both bromophenol blue and heparin combine with marcescin but neither was able to reverse the inhibition to any extent.

Bromophenol blue itself did not inhibit the growth of staphylococci up to concentrations of $0.1 \%$. When $0.025 \%$ of bromophenol blue was mixed with decreasing concentrations of marcescin in broth, which was then seeded with staphylococci, there was growth only at about $1 \mathrm{u} . / \mathrm{ml}$. and none at $3 \mathrm{u} . / \mathrm{ml}$., showing that bromophenol blue did not neutralize the activity of marcescin to any great extent. Heparin precipitates marcescin when both are at a concentration of $0.1 \mathrm{mg} . / \mathrm{ml}$. and causes some diminution in the antibacterial activity. Thus addition of an amount of heparin from 10 to 1000 times that of the marcescin used diminished the activity of marcescin to $25 \%$, but failed to enable staphylococci to grow after treatment with large concentrations of the antibiotic.

Serratia marcescens. In view of the strong adsorption of marcescin by bacterial cells it was important to see to what extent $S$. marcescens adsorbed it, and what effect this had on the titres of culture fluids. S. marcescens cells were washed off agar slopes ( 1 slope $/ \mathrm{ml}$.) into broth, water $3 \%$ ammonium citrate solution, each containing $150 \mathrm{u} . / \mathrm{ml}$. of marcescin. After $30 \mathrm{~min}$. at $37^{\circ}$ the organisms were spun down and the supernatant assayed. Table 9 gives the results of two experiments and shows that citrate prevented the adsorption; this may explain the efficacy of citrate media in producing the antibiotic.

The bacterial cells in Exp. 2 were extracted with 3 volumes of acetone, spun down and then re-extracted with $0.05 \mathrm{~N}-\mathrm{HCl}$ in $75 \%$ acetone. The extracts were evaporated to dryness, leached with water and the aqueous extract spun clear. This contained about 60 units, or more than half of the adsorbed antibiotic. It appears that citrate media, combined with the acid acetone method of extraction reasonably safeguarded against losses due to adsorption on the bacteria.

Table 9. Adsorption of marcescin by Serratia marcescens

\begin{tabular}{|c|c|c|c|c|}
\hline & \multirow{2}{*}{$\begin{array}{l}\text { Units } \\
\text { addeed }\end{array}$} & \multicolumn{3}{|c|}{ Units in supernatant from } \\
\hline & & Water & $\overbrace{\text { Broth }}$ & $3 \%$ citrate \\
\hline $\begin{array}{l}\text { Exp. } 1 \\
\text { Exo. } 2\end{array}$ & $\begin{array}{l}120 \\
120\end{array}$ & $\begin{array}{r}20 \\
8\end{array}$ & $\begin{array}{r}7 \\
16\end{array}$ & $\dot{128}$ \\
\hline
\end{tabular}

Table 10. Adsorption of marcescin by Serratia marcescens from water

\begin{tabular}{|c|c|c|c|c|}
\hline & \multicolumn{4}{|c|}{ Culture grown at } \\
\hline & \multicolumn{2}{|c|}{$\mathbf{2 4}^{\circ}$} & \multicolumn{2}{|c|}{$37^{\circ}$} \\
\hline & In citrate & In broth & In citrate & In broth \\
\hline Units added & $\mathbf{3 0 0}$ & 800 & $\mathbf{3 0 0}$ & $\mathbf{8 0 0}$ \\
\hline Units in supernatant & 7 & 12 & 26 & $\mathbf{2 6}$ \\
\hline $\begin{array}{l}\text { Units extracted from } \\
\text { cells by } 75 \% \text { acid }\end{array}$ & 120 & 80 & 400 & 80 \\
\hline
\end{tabular}


Cells grown in citrate medium or in broth adsorbed marcescin at $37^{\circ}$ or at $24^{\circ}$ to the same extent. The averages of three experiments are shown in Table 10.

Resistant forms. After eight to ten subcultures, some of several days' duration, Staphylococcus aureus could grow in $1 \mathrm{u} . / \mathrm{ml}$. of broth and Pasteurella septica in $0.5 \mathrm{u} . / \mathrm{ml}$. This small amount of acquired resistance was lost at the first subculture in absence of the antibiotic. 'Adapted' organisms tend to grow in tight pellets or strings at the bottom of the tube.

Action on enzyme systems. Marcescin inhibited the reduction of methylene blue by staphylococci in broth even in the presence of succinate, lactate, acetate, aspartate and fumarate. A concentration of $10-50 \mathrm{u} . / \mathrm{ml}$. partially, and $100-500 \mathrm{u} . / \mathrm{ml}$. totally, inhibited the enzyme systems involved. Marcescin also inhibited the reduction by Staphylococcus aureus of nitrate to nitrite. Five u./ml. diminished the reduction of nitrate to about $20 \%$ of the control, and $15 \mathrm{u} . / \mathrm{ml}$. halved the rate of methylene-blue reduction in presence of succinate.

The effects were used as a means of quickly assaying culture fluids to judge when maximum titre had been reached. The amount of inhibition of enzyme action was not always proportional to the unitage measured by inhibition of growth; the tests were therefore abandoned as a means of assaying culture fluids.

Toxicity. Marcescin is very toxic, with an M.L.D. for mice orally or intravenously of under $62 \mathrm{mg}$. $/ \mathrm{kg}$. The $\mathrm{LD} 50$ for mice was $125 \mathrm{mg} . / \mathrm{kg}$. by subcutaneous injection, and the M.L.D. by the intraperitoneal route was $2 \cdot 5 \mathrm{mg} / \mathrm{kg}$. Soon after injection the animals became very excited for a brief period, then lethargic, and just before death a series of rapid tremors ran from the head over the dorsal surface. In animals dying from intraperitoneal or intravenous injection there was acute abdominal haemorrhage and engorged auricles and right ventricle. Injection of doses of 1-5 mg. into the shaved skin of rabbits appeared to inhibit the infection by Staph. aureus injected at the same time, but also caused severe necrosis.

Action on blood cells. Horse blood was haemolysed immediately by a concentration of $1.25 \mathrm{mg} . / \mathrm{ml}$., and in $2 \mathrm{hr}$. by $0.005 \mathrm{mg}$. $/ \mathrm{ml}$.

The action on leucocytes was determined by the method of Abraham, Chain, Fletcher, Gardner, Heatley, Jennings \& Florey (1941); direct observation under dark ground illumination. A concentration of $1.25-2.5 \mathrm{mg} . / 100 \mathrm{ml}$. caused loss of motility of about $50 \%$ of cells in $1 \mathrm{hr}$; t the corresponding figure for penicillin is $500-1000 \mathrm{mg} . / 100 \mathrm{ml}$. The effect on phagocytosis was less than would be expected from the above figures. In concentrations of 40 and $4 \mathrm{mg}$./ $100 \mathrm{ml}$. leucocytes engulfed up to half the number of bacteria that were taken up by the control leucocytes. At $0.4 \mathrm{mg}$. $/ 100 \mathrm{ml}$. there was no inhibition of phagocytosis. In these experiments the bacteria were added immediately after the drug.

Therapeutic properties. Three doses of $1 \mathrm{mg}$. subcutaneously at 0,14 and $28 \mathrm{hr}$. after infection failed to protect mice against 100 M.L.D. of Staph. aureus ('Burroughs Wellcome mouse virulent strain') administered with mucin, or against 5 lethal doses of Staph. aureus. Similar subcutaneous doses failed to protect mice against 100-1000 M.L.D. of a mouse-virulent group A haemolytic 
streptococcus, 'Richards', given intraperitoneally. Three doses of $0.5 \mathrm{mg}$. subcutaneously at 0,14 and $25 \mathrm{hr}$., or 5 doses of $0.2 \mathrm{mg}$. at $0,6,14,20$ and $25 \mathrm{hr}$., failed to protect mice against 100 M.L.D. of Pasteurella septica (N.C.T.C. 2848).

\section{DISCUSSION}

It is not certain whether the activity of culture filtrates reported by Eisler \& Jacobsohn (1935) and by Lichstein \& van der Sand (1946) was due to marcescin. All the active substances were apparently colourless and thermostable and their antibacterial spectra are similar. Eisler found activity in! his cultures of Serratia marcescens at 2-24 days at $22-26^{\circ}$ or $1-4$ days at $37^{\circ}$. Lichstein's substance was not present at $18 \mathrm{hr}$. |but appeared in 3-week-old cultures. Our antibiotic appears to differ from these. It is not produced at $37^{\circ}$, and is present in maximum yield at $18 \mathrm{hr}$. at $24^{\circ}$, when using large seedings and vigorous aeration. Under less favourable conditions of growth it may be present for as long as $\mathbf{8}$ days, but it disappears from broth culture and would not survive for 3 weeks.

In our experience there was little connexion between the amounts of pigment and antibiotic formed except that both tended to be present during rapid growth. Pigment formation was poor and transitory in chemically defined media, and marcescin was produced equally well by the pigmented and achromogenic variants of our culture. In its resistance to digestion by proteolytic enzymes it is similar to other polypeptide antibiotics, e.g. bacitracin (Anker et al. 1948).

The activity of marcescin does not appear to depend on the presence of the haemorrhagic polysaccharide of Hartwell et al. (1943). Our purest product contained only traces of carbohydrate (probably impurity), and whereas marcescin is stable for several hours at $100^{\circ}$ or in $\mathrm{N}-\mathrm{HCl}$ for $6 \mathrm{hr}$. at $100^{\circ}$, the polysaccharide of Hartwell et al. was rapidly destroyed at $100^{\circ}$ or in $2 \mathrm{~N}-\mathrm{HCl}$ at $37^{\circ}$.

Marcescin is difficult to free from acidic impurities; when converting the picrate to hydrochloride the process must be repeated several times to get a product free from picric acid. The trace of carbohydrate and phosphorus in our purest product is probably due to adsorbed nucleoprotein.

The most characteristic feature in the antibiotic action of marcescin is the ease with which it is adsorbed by bacteria. Staphylococci are able to remove $98 \%$ of a high concentration of marcescin from solution. Owing to this it is not possible to say whether high concentrations of marcescin are bactericidal or bacteriostatic, since enough is carried over in the inoculum to continue to inhibit growth. The so-called bactericidal action of other antibiotics may be due to a similar phenomenon. The strong adsorption of the antibiotic by bacteria may account in part for its activity at high dilutions, and for the need for higher concentrations to inhibit larger implants of bacteria. 


\section{REFERENCES}

Abraham, E. P., Chain, E., Fletcher, C. M., Gardner, A. D., Heatley, N. G., Jennings, M. A. \& Florey, H. W. (1941). Further observations on penicillin. Lancet, ii, 182.

ANker, H. S., Johnson, B. A., Goldberg, J. \& Melleney, F. L. (1948). Bacitracin: methods of production, concentration and partial purification, with a summary of the chemical properties of crude Bacitracin. J. Bact. 55, 249.

Bergey, D. H. (1948). Manual of determinative bacteriology, ed. Breed, R. S., Murray, E. G. D. \& Hitchins, A. P., 6th ed. London: Baillière, Tindall and Cox.

Breed, R. S. \& Breed, M. E. (1926). Serratia indica Bergey, the red chromogenic bacterium originally isolated by Koch in India. J. Bact. 11, 76.

Dubos, R. J. \& Davis, B. D. (1946). Factors affecting the growth of tubercle bacilli in liquid media. J. exp. Med. 83, 10.

Dufrenox, J. \& Pratt, R. (1947). Cytochemical mechanisms of penicillin action. I. Oxidation-reduction levels. J. Bact. 53, 637.

Eisler, M. \& JacoBsoHN, I. (1935). Über die antagonistisch Wirkung steriler Bouillonextracte aus Bacterium prodigiosus. Z. Hyg. InfektKr. 117, 76.

ELFORD, W. J. (1931). A new series of collodion membranes suitable for general bacteriological use, especially in filterable virus studies. J. Path. Bact. 34, 505.

Hartwell, J. L., Shear, M. J. \& Adams, J. R. (1943). Nature of the haemorrhageproducing fraction from Serratia marcescens culture filtrate. $J$. Nat. Cancer Inst. 4, 107.

HeTtCHE, H. O. (1932). Untersuchungen über die bakteriziden und anthrakoziden Bestandteil von Bacillus pyocyaneus und Bacillus prodigiosus. Arch. Hyg., Berl., 107, 337.

Lichstein, H. C. \& van der SAND, V. (1946). The antibiotic activity of Violacein, Prodigiosin and Phthiacol. J. Bact. 52, 145.

Marchal, J. G. \& Girard, T. (1947). Phénomenès d'oxydoréduction mis en evidence avec le molybdate d'ammoniaque ajouté dans les cultures bactériennes. C.R.Soc. Biol., Paris, 141, 118.

Pederson, C. S. \& Breed, R. S. (1928). The fermentation of glucose by organisms of the genus Serratia. J. Bact. 16, 163.

REED, G. B. (1937). Independent variation of several characteristics of $S$. marcescens. J. Bact. 34, 255. 